\title{
Retrospective evaluation of 106 Behçet's disease patients in Giresun province
}

\section{Giresun ilindeki 106 Behçet hastasının retrospektif değerlendirilmesi}

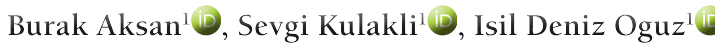 \\ ${ }^{1}$ Dept. of Dermatology, Giresun University Faculty of Medicine, Giresun, Turkey
}

\section{Abstract}

Background Behçet's disease (BD) is a multisystem inflammatory disorder which is an important cause of morbidity in Turkey.

Objective We aimed to investigate the demographical and clinical features of patients with BD followed up in our department in Faculty of Medicine in Giresun University Training and Research Hospital.

Methods The hospital records of patients with BD who attended the dermatology department between 2006-2019 were retrospectively evaluated. One hundred and six patients who met the diagnostic criteria of International Study Group for BD were included in the study. The clinical and demographic characteristics, including the age of onset, disease duration, mucocutaneous findings and systemic involvements were recorded.

Results Of the 106 patients in the study, 64 (60.4\%) were female, 42 (39.6\%) were male, and the female-to-male ratio was 1.52:1. The median age at the onset of the disease was 38 years, and the median disease duration was 9 years (range 1-40 years). The most common finding was recurrent oral ulcers (100\%) followed by genital ulcers (86.6\%), ocular involvement (52.8\%), erythema nodosum (49.1\%), articular involvement (45.3\%), papulopustular lesions (34\%), positive pathergy test (21.7\%), vascular involvement (14.2\%), gastrointestinal involvement (9.4\%), neurologic $(2.8 \%)$ and genitourinary involvement (2.8\%). Papulopustular lesions were seen statistically significantly more frequent in men $(P=0.047)$.

Conclusion In our study, we presented the demographical and clinical features of patients with BD in a single center in Giresun. Major findings were mucocutaneous ones and most common extracutaneous involvements were eyes and joints.

Key words: Behçet's disease, epidemiology, demographical characteristics, Turkey

\section{Özet}

Amaç Behçet hastalığı (BH) Türkiye'de önemli morbiditelere neden olan, multisistemik inflamatuvar bir hastalıktır. Bu çalışmada Giresun Üniversitesi Tıp Fakültesi Eğitim ve Araştırma Hastanesi dermatoloji kliniğinde BH tanısı ile takip edilen hastaların demografik ve klinik özelliklerinin belirlenmesi amaçlandı.

Corresponding author: Burak Aksan, Dept. of Dermatology, Giresun University Faculty of Medicine, Giresun, Turkey Phone: +90 533 2128421, E-mail: aksanburak@gmail.com

Received: 4 December 2019 Accepted: 23 March 2020

Conflicts of Interest: None

Funding: None

(c) (i) (8) This work is licensed under a Creative Commons Attribution-NonCommercial 4.0 International License. 
Yöntem 2006-2019 yllları arasında hastanemiz dermatoloji kliniğinde BH tanısı ile izlenen hastaların kayıtları geriye dönük olarak incelendi. Uluslararası Behçet hastalığı Çalışma Grubu'nun tanı kriterlerini karşılayan toplam 106 hasta çalışmaya dâhil edildi. Başlangıç yaşı, hastalık süresi, mukokütanöz bulgular ve sistemik tutulumlar dâhil olmak üzere klinik ve demografik özellikler kaydedildi.

Bulgular Çalışmaya alınan 106 hastanın 64'ü kadın (\%60.4), 42'si erkekti (\%39.6). Kadın/erkek oranı 1.52:1 idi. Ortalama başlangıç yaş ortancası 38 yaş, hastalık süresi ortancası 9 yıl (1-40) olarak saptandı. En sık görülen klinik bulgu tekrarlayan oral ülserlerdi, hastaların tamamında mevcuttu. Oral ülserleri sirasıyla genital ülser (\%81.1), göz tutulumu (\%52.8), eritema nodozum (\%49.1), eklem tutulumu (\%45.3), papülopüstüler lezyonlar (\%34), pozitif paterji testi (\%21.7), damar tutulumu (\%14.2), gastrointestinal tutulum (\%9.4), nörolojik (\%2.8) ve genitoüriner tutulum (\%2.8) takip etmekteydi. Erkeklerde papülopüstüler lezyon sıklığı kadınlara göre anlamlı oranda daha yüksek saptandı $(P=0.047)$.

Sonuç Çalışmamızda Giresun'da tek merkezli olarak takip edilen Behçet hastalarının demografik ve klinik verileri sunuldu. Mukokütanöz bulguların ön planda olduğu hastalarda göz ve eklem en sık tutulan deri dışı organlar olarak saptandı.

Anahtar kelimeler: Behçet hastalı̆̆, epidemiyoloji, demografik özellikler, Türkiye

\section{Introduction}

Behçet's disease (BD) is a chronic, relapsing, inflammatory multisystem disease of unknown etiology. The disease was first described in 1937 by Turkish dermatologist Hulusi Behçet as a triad of recurrent oral ulcers, genital ulcers and uveitis. ${ }^{1}$ Then it has shown that BD is a multisystemic disease with articular, gastrointestinal, neurologic, urogenital, vascular, pulmonary and cardiac involvement. ${ }^{2}$ The disease is most prevalent in regions along the "Silk Route" which extends from the Mediterranean countries to the Middle East and Far East. ${ }^{3}$ The highest prevalence rates have been reported in Turkey (up to 1/250) and lower prevalence rates have been reported in northern European countries (0.64/100000) and the United States (0.12$0.33 / 100000) .^{4,5}$ BD usually starts around the third or fourth decades of life, and prevalence is roughly equal in male and female. ${ }^{3,6}$ Disease expression vary in different ethnic groups and geographic areas. These differences could be related to genetic and environmental influences. The exact pathogenesis of Behçet's syndrome is unknown, but it is presumed to be multifactorial implicating genetic, infectious and immunologic factors. The predominant histopathological feature of $\mathrm{BD}$ is vasculitis which can involve all veins, arteries and vessels of all sizes. ${ }^{7}$ Because of the lack of a pathognomonic laboratory test, the diagnosis of $\mathrm{BD}$ is primarily based on both clinical criteria and on the exclusion of other diseases. For BD diagnosis, International Study Group (ISG)'s criteria, which requires in addition to recurrent oral ulcers any two of the following findings namely recurrent genital ulcers, typical ocular lesions, typical cutaneous lesions or a positive patergy test, is the most widely used one. ${ }^{8}$

In our study, we aimed to investigate the demographical and clinical features of patients with BD followed up in Giresun University Faculty of Medicine Training and Research Hospital.

\section{Methods}

The approval of Giresun University Clinical Research Ethics Committee was obtained for our study. We performed a retrospective review of the records of 106 cases diagnosed as BD ( 64 females, 42 males) who had been followed up by the departments of dermatology in Giresun Universty Training and Research Hospital, formerly Giresun State Hospital, between 2006-2019. Diagnosis of BD was made according to the criteria of ISG for BD. All patients' age, sex, age at onset, disease duration, family history, mucocutaneous findings (oral ulcers, genital ulcers, erythema nodosum, papulopustular lesions), systemic involvements ( ocular, articular, gastrointestinal, neurologic, vascular, genitourinary) and pathergy test result were recorded. The examinations of the patients for specific organ involve- 
ments were carried out by the specialist physicians of the relevant clinics.

All data were assessed using the Statistical Package for the Social Sciences (SPSS) software package version 21.0. The suitability of the variables to normal distribution was examined using the Kolmorogov-Smirnov test. Descriptive analyzes were performed using median and minimum-maximum interval for variables not having normal distribution, and arithmetic mean \pm standard deviation for data showing normal distribution. The t-test (for comparison of a characteristic having a normal distribution) or Mann-Whitney U test (for comparison of a characteristic not showing a normal distribution) was used to compare continuous variables. Cross-tables were used to evaluate the qualitative data between the two groups. A chi-square test and Fisher's exact test were used for the categorical variables. A p-value of less than 0.05 was considered significant.

\section{Results}

Among 106 patients reviewed in the study, 64 patients (60.4\%) were female 42 patients $(39.6 \%)$ were male, and female to male ratio was 1.52:1

The median age at the onset of the disease was 38 years, and the median disease duration was 9 years (range, 1-40 years). In female patients, the median age at onset was 40.5 , in male patients that was 38 . There was no statistically significant difference between male and female patients in terms of disease duration and age at onset $(P=0.657)(P=0.541)$. In one patient, the disease was started before 16 years ( juvenile-onset $\mathrm{BD}$ ) and he had ocular involvement.

Table 1 shows the main clinical characteristics of patients. All patients had recurrent oral ulcers (100\%). The second common finding was genital ulcers (81.1\%) followed by erythema nodosum (49.1\%) and papulopustular lesions (34\%). Twenty-three patients $(21.7 \%)$ had a positive pathergy test.
Table 1. Demographic and clinical characteristics of all patients

\begin{tabular}{lcc}
\hline Patient characteristics & $\mathrm{n}$ & $\%$ \\
\hline Sex & & \\
$\quad$ Male & 42 & 39.6 \\
$\quad$ Female & 64 & 60.4 \\
Mucocutaneous findings & & \\
$\quad$ Oral ulcers & 106 & 100 \\
$\quad$ Genital ulcers & 86 & 81.1 \\
$\quad$ Erythema nodosum & 52 & 49.1 \\
$\quad$ Papulopustuler lesions & 36 & 34 \\
$\quad$ Pathergy test positivity & 23 & 21.7 \\
Ocular involvement & 56 & 52.8 \\
Articular involvement & 48 & 45.3 \\
Neurologic involvement & 3 & 2.8 \\
Gastrointestinal involvement & 10 & 9.4 \\
Vascular involvement & 15 & 14.2 \\
Genitourinary involvement & 3 & 2.8 \\
Family history positivity & 8 & 7.5 \\
\hline
\end{tabular}

Ocular involvement was the most common extracutaneous finding (52.8\%). Forty-eight patients (45.3\%) had joint, 15 patients (14.2\%) had vascular, ten patients $(9.4 \%)$ had gastrointestinal, three patients (2.8\%) had neurologic involvement and three patients (2.8\%) had orchitis.

Comparison of demographic and clinical features frequencies according to gender are shown in Table 2. Papulopustular lesions were significantly more frequent in men than in women ( $45.2 \%$ vs. $26.6 \% ; P=0,047$ ). For other clinical findings, there was no statistically significant difference between two genders. 
Table 2. Distribution of demographic and clinical features between genders

\begin{tabular}{|c|c|c|c|}
\hline & Female $(n=64)$ & Male $(n=42)$ & $\mathrm{P}$ \\
\hline Age $($ median \pm SD $)$ & $43.66 \pm 13.13$ & $44.21 \pm 10.56$ & 0.810 \\
\hline Age of onset (median,min-max) & $40.5(16-72)$ & $38(21-59)$ & 0.541 \\
\hline Disease duration (year) (median, range) & $9.5(1-35)$ & $8.5(1-40)$ & 0.657 \\
\hline Oral ulcers, n (\%) & $64(100)$ & $42(100)$ & \\
\hline Genital ulcers, n (\%) & $54(84.4)$ & $32(76.2)$ & 0.292 \\
\hline Erythema nodosum, n (\%) & $33(51.6)$ & $19(45.2)$ & 0.524 \\
\hline Papulopustuler lesions, n (\%) & $17(26.6)$ & $19(45.2)$ & 0.047 \\
\hline Pathergy positivity, n (\%) & $11(17.2)$ & $12(28.6)$ & 0.164 \\
\hline Ocular involvement, n (\%) & $33(51.6)$ & $23(54.8)$ & 0.747 \\
\hline Articular involvement, n (\%) & $29(45.3)$ & $19(45.2)$ & 0.994 \\
\hline Neurologic involvement, n (\%) & $2(3.1)$ & $1(2.4)$ & 1.000 \\
\hline Gastrointestinal involvement, n (\%) & $6(9.4)$ & $4(9.5)$ & 1.000 \\
\hline Vascular involvement, $\mathrm{n}(\%)$ & $6(9.4)$ & $9(21.4)$ & 0.082 \\
\hline Family history positivity, n (\%) & $5(7.8)$ & $3(7.1)$ & 1.000 \\
\hline
\end{tabular}

\section{Discussion}

Behçet's disease is a vasculitis of unknown etiology with remission and exacerbations. ${ }^{9}$ Regional differences in clinical characteristics may exist between populations. The highest incidence is seen along the ancient Silk Road from the Mediterranean countries to the Middle East. ${ }^{10}$ The aim of our study is to present the clinical features of BD in Turkey which is an endemic country for BD.

It usually affects young adults between 20 and 40 years of age. ${ }^{11}$ The age of onset has been most commonly reported ranging from 24.7 to 35.2 . In our study, the median age was 38 respectively, which was similar to the results of the study of Bang Et al. from Korea. ${ }^{12}$

The incidence of the disease in men and women varies by country. The male to female ratios in our study were $0.66: 1$. This is similar to the reports from USA $(0.4: 1)$ and European countries (0.6:1). However, most series from other countries like Israel (2.3:1), Japan $(1.7: 1)^{13}$ and Tur- key $\left[(1.6: 1)^{14}\right.$ v.s. $\left.(1.03: 1)^{15}\right]$ a male predominance is seen. The etiopathogenesis of $\mathrm{BD}$ is still not clarified but genetic predisposition has been postulated in various studies. We noted a positive family history as of $7.8 \%$, which is similar to the report of Gürler et al. (8\%). ${ }^{15}$

According to the criteria of the ISG of BD, oral aphthae is a definite diagnostic criterion for BD diagnosis. ${ }^{8}$ Therefore all of our patients in both groups had oral aphthous lesions.

The incidence of genital ulcers in BD varies according to different countries. In previous studies, these ratios were reported as $78 \%-94.1 \%$ in Turkey ${ }^{14,16-17}, 73 \%$ in Japan, $78 \%$ in Germany, $78 \%$ in Greece, and $80.2 \%$ in Korea. ${ }^{12}$ In our study this ratio was found $81.1 \%$.

In two previous reports, the prevalence of cutaneous lesions, one of the major criteria, were $79.9 \% .{ }^{18-19}$ The cutaneous lesions mainly divided into two groups as erythema nodosum and papulopustular lesions. 
In previous studies, the incidence of erythema nodosum was reported between $5 \%-46.7 \%$ in the Middle East, $25 \%-78 \%$ in Europe and $36.6 \%-47.6 \%$ in our country. In our study, this ratio was $52 \%$ similar to ratios in Europe. ${ }^{20}$

The incidence of papulopustular lesions has been reported in the literature in $34 \%-70 \%$. Most of them have reported that papulopustular lesions are more common in male patients than in women. ${ }^{16}$ In our study, this ratio was $34 \%$ and papulopustular lesions were significantly more frequent in male patients $(P=0.047)$.

Positive pathergy test is, together with the mucocutaneous and systemic manifestations, more frequently noted in the active stage of the disease and has a high diagnostic value. ${ }^{15}$ In our study, this ratio was found in $\% 21.7$ patients. In Turkey, this ratio was given as $8 \%-57.3 \% .^{17,21-22}$

Eye involvement is one of the most important causes of morbidity in BD. If serious follow-up and necessary precautions are not taken, some cases may develop blindness. The frequency of ocular involvement is around $50 \% .{ }^{23}$ Ocular involvement rate was reported $27.7 \%-39 \%$ in Turkey ${ }^{20} ; 28.9 \%-76 \%$ in the Middle East $^{25}, 35 \%-92 \%$ in Europe ${ }^{24}$ and $51.2 \%$ in Korea. ${ }^{12}$ It's also more common in men than women. ${ }^{15,17}$ In our study, this ratio was found $52.8 \%$ and it is more frequent in the male group (54.8\%) compared with the female group (51.6\%) But there was no statistically significant difference between two genders.

Although arthritis and arthralgia, common joint problems, are not included in the diagnosis criteria, they are the main findings in half of the patients. ${ }^{26}$ Joint involvement has been reported between $16 \%$ and $93 \%$ from different countries. ${ }^{15,27-28}$ In our study, this ratio was found $48 \%$.

Gastrointestinal system (GIS) involvement has been determined at different rates in different countries by different studies. In Japan and Korea the prevalence of GIS involvement was reported as high as $15-40 \%$. However it was low in Israel and Turkey as a ratio of $0 \%-5 \% .^{12,14,16}$ In our study 10 patients (9.4\%) had GIS involvement and frequencies were similar between male and female genders.

Neurological involvement is one of the most feared organ involvement in BD. In spite of being considered among minor criteria, the prevalence of the neurological involvement is between $2.2 \%$ and $50 \% .{ }^{29} \mathrm{Al}-$ though there are conflicting rates for the prevalence of this involvement in large series in Turkey, this ratio is between $5 \%-7 \% .^{22,30}$ Neurological involvement was observed $23 \%$ in the $\mathrm{USA}^{31}$, and $17.1 \%$ in Italy. ${ }^{32}$ In our study, we found this ratio as $2.8 \%$. Neurological involvement rate was similar between male and female genders.

Vascular involvement is a major cause of morbidity and sometimes mortality. Vascular involvement in BD was reported $7.4 \%-33 \%$ in the previous literature. It was reported that the involvement in male patients was 5.6 times higher than in female patients. ${ }^{12,15}$ In our study we found it as $14.2 \%$, and the frequency of this involvement is 2.28 times higher in our male patients. But there was no statistically significant difference between two genders.

In our study, we presented the demographical and clinical features of patients with BD in a single center in Giresun. Major findings were mucocutaneous ones and most common extracutaneous manifestations were eye and joint involvement.

\section{References}

1. Tuzun Y, Fresko I, Mat MC, et al. Behçet Sendromu. In: Dermatoloji, 3rd ed. İstanbul, Nobel Tip Kitabevleri 2008;913-28.

2. Sallakci N, Bacanli A, Coskun M, Yavuzer U, Alpsoy E, Yegin O. CTLA-4 gene 49A/G polymorphism in Turkish patients with Behcet's disease. Clin Exp Dermatol 2005;30:546-50.

3. Alpsoy E, Zouboulis CC, Ehrlich CE. Mucocutaneous lesions of Behcet's disease. Yonsei Med J 2007;48:573-85.

4. Azizlerli G, Kose AA, Sarica R et al. Prevalence of Behcet's disease in Istanbul, Turkey. Int J Dermatol 2003;42:803-6.

5. Sakane T, Takeno M, Suzuki N, Inaba G. Behcet's disease. N Engl J Med 1999;341:1284-91. 
6. Cho SB, Cho S, Bang D. New insights in the clinical understanding of Behcet's disease. Yonsei Med J 2012; 53:35-42.

7. Yurdakul S, Hamuryudan V, Yazıcı H. Behçet syndrome. Curr Op Rheum 2004;16:38-42.

8. International study group for Behçet's disease. Criteria for diagnosis of Behçet's disease. Lancet 1990;335:1078-80.

9. Onder M, Gurer MA. Behçet's disease: an enigmatic vasculitis. Clin Dermatol 1999;42:803-6.

10. Verity DH, Marr JE, Ohno S, Wallace GR, Stanford MR. Behçet's disease, the Silk Road and HLA-B51: historical and geographical perspectives. Tissue Antigens 1999;54:213-20.

11. Hegab S, Mutava S. Immunopathogenesis of Behçet's disease. Clin Immunol 2000;42:803-6.

12. Bang DS, Oh SH, Lee KH, Lee ES, Lee SN. Influence of sex on patients with Behçet's disease in Korea. J Korean Med Sci 2003;18:231-5.

13. Teter MS, Hochberg MC. Diagnostic criteria and epidemiology. In: Plotkin GR, Calabro JJ, O'Duffy JD, editors, Behçet's disease: A contemporary synopsis. New York Futura Publishing 1988;9-21.

14. Karincaoglu Y, Coskun BK, Seyhan M, Aki T. Demographical and clinical characteristics of Behçet's disease patients in Malatya and Elazig. Turkiye Klinikleri J Dermatol 2005;15:65-70.

15. Gurler A, Boyvat A, Tursen U. Clinical manifestations of Behcet's disease: an analysis of 2147 patients. Yonsei Med J 1997;38:423-7.

16. Alpsoy E, Donmez L, Bacanli A, Apaydin C, Butun B. Review of the chronology of clinical manifestations in 60 patients with Behçet's disease. Dermatology 2003;207:354-6.

17. Tursen U, Gurler A, Boyvat A. Evaluation of clinical findings according to sex in 2313 Turkish patients with Behçet's disease. Int J Dermatol 2003;42:346-51.

18. Yazici H, Tuzun Y, Pazarli H, et al. Influence of age of oncet and patient's sex on the prevalence and severity of manifestations of Behçet's syndrome. Ann Rheum Dis 1984;43:783-9.

19. Madanat W, Fayyad F, Verity D, Zureikat H. Influence of sex on Behçet's disease. In: Bang D, Lee ES, Lee S, editors, Behçet's disease: Proceeding of the 8th and 9th International Conference on Behçet's disease. Seol: Design Mecca Publishing 2001;90-3.

20. Uslu M, Karaman G, Savk E, Şendur N, Yılmaz E Aydın'da Behçet hastalığı deneyimi:67 hastanın retrospektif değerlendirilmesi. ADU Tıp Fakultesi Dergisi 2008;9:21-6.

21. Dogan B, Taskapan O, Harmanyeri Y. Prevalance of pathergy test positivity in Behçet's disease in Turkey. J Eur Acad Dermatol Venereol 2003;17:228-9.
22. Karabacak E, Aydin E, Dogan B, et al. Behçet hastalığı: 182 hastanın klinik ve demografik özellikleri Turkderm 2014;48:121-6.

23. Ozyazgan Y. Behçet Hastalığında Göz Tutulumu. Turkderm 2009;43:48-53.

24. Zouboulis CC, Kotter I, Djawari D, et al. Epidemiological features of Adamantiades-Behçet's disease in Germany and in Europe. Yonsei Med J 1997;38:411-22.

25. Saylan T, Mat C, Fresko I, Melikoglu M. Behçet's disease in Middle East. Clin Dermatol 1999;17:209-23.

26. Can M, Direskeneli H: Behçet hastalığında kas, iskelet sistemi ve damar tutulumu. Turkderm 2009;43 Özel Sayı:54-60.

27. Cheng TK, Thong BY, Chng HH. Behçet's disease: experience in a tertiary rheumatology center in Singapore and a review of the literature. Ann Acad Med Singapore 2004;33:510-4.

28. Seaman G, Pearce RA. Behcet's Disease manifestation in a population drawn from the UK Behcet's Syndrome Society. Behcet's Disease. Ed. Hamza M. Tunisia, Pub Adhoua 1997;196-9.

29. Al-Araji A, Sharquie K, Al-Rawi Z. Prevalence and pattern of neurological involvement in Behcet's disease: a prospective study from Iraq. J Neurol Neurosurg Psychiatry 2003;7:608-13.

30. Akman-Demir G. Behçet Hastalığında Nörolojik Tutulum. Turkderm 2009;43 Özel Sayı:61-4.

31. Davatchi F, Shahram F, Chams C, Chams H, Nadji A. Behçet's disease. Acta Medica Iranica 2005;43:233-42.

32. Pipitone N, Boiardi L, Olivieri I, et al: Clinical manifestations of Behçet's disease in 137 Italian patients: results of a multicenter study. Clin Exp Rheumatol 2004;22:46-51. 